SLAC- PUB $-95-6755$

\title{
RF Pulse Compression
}

\author{
for Future Linear Colliders*
}

\author{
Pehil B. WILSON
}

Stanjond Linear Accleritor Center

Stanford University. Stanford, CA 94300

Presented at the Conference on Pulsed RF Sourres for Lincar Golliders

Montauk, Long lsland, New York, October 2-7, 1994 


\section{ARSTRACT}

Future (nousuperconducting) linear colliters will rexuire very high values of jeak of pourer per meter of acculerating structure. The role of $\mathrm{r} f$ pulse comprossion in prostucing this power is extmined within the context of un all of system design for three future colliders at energits of 1.0-1.5 TeV, $5 \mathrm{TeV}$ and $25 \mathrm{TeV}$. It order keep the averuge AC input power and the length of the accelerator within rensonuble limits, 11 collider in the 1.0-1.5 TeV cnergy range will probably be built at an $x$-band of frequency, and will rexulue a pesak power on the order of 150-200 NWW por meter of accelerntingt structure. $\mathrm{A} 5 \mathrm{TeV}$ collider at $\mathbf{3} \mathrm{GHz}$ with a reasonable length (35 km) and $\mathrm{AC}$ injult porer (225 MWV) would require about $550 \mathrm{MW}$ per meter of structure. Tro-bewn accelerilors can aclieve poak pouers of this order by applying de pulse compression techniques (induction linuc modules) to produce the drive beam. Klystron-draten colliders achieve high penk puner by a combintion of ds pulse compression (moduluters) and $\mathrm{r}$ pulse compression, with Bbout the same overall rf system efliciney $(3(1-40 \%)$ at a two-beom collider. A high guin (6.8) three-stage binury pulse comprosion system with high efficiency (80\%) is described. which (compured to a SLED-II system) chn be used to reduce the klystron peak power by about a factor of turn, or alternately, to cut the number of klystrons in half for a 1.0-1.5 TeV x-bind collider. For a $5 \mathrm{TeV}$ klystron-driven collider, a high gain, high nfficiency of pulse cotupressions systam is estrent int. 


\section{RF PARAMETERS FOR FUTURE LINEAR COLLIDERS}

Linear colliders tw they exist at present (the SLC colliclet at SLAC), and as they ure foreseen for the future (we will not consider superconducting colliters here), require very high values of ptak of pulse pourer per mets of acceleriating structure. For example, at the SLC operating gradient of $21 \mathrm{MV} / \mathrm{m}$, the requited peak power is $13 \mathrm{MW} / \mathrm{m} 1$. Since each klystron feed $12 \mathrm{~m}$ of structure, a klystron output powar of alsout $160 \mathrm{Mll}$ uould be repuired without of pulse compresitun. $A$ SI,ED-type pulse compression system with a jower gin of 2.6 reduces the repusires kitystrot) output prower to about $60 \mathrm{MW}$.

The s-bnnd (2.850 GH2) SLC linac produces an energy of abont $50 \mathrm{GeV}$ in Iength which is slightly less thun $3 \mathrm{~km}$. A world-wide etfort is now underway to design a next-step linear collirjer with a center-of-untss encrgy of $500 \mathrm{GeV}$. One strajghtforward wry to achiare such a machinc is to extend the length of un SLC-like liuac by a faclor of 10 , to nround $30 \mathrm{~km}$. There is, in fact, a propmenl for such an s-band lincar collider (SBLC) heing, put forkard by the DESY laboratory it Hamburg, Germany. Whilu the terhnology for such a colliter is inderd guite clove to that in existence today, it is difficult to extend this design to higher energies witlont the length beconing uncomfortably long and the $\mathrm{AC}$ power consumption becoming urrounfortably high. To reach encrgics of I TeV and beyond. it is necessury to consider higher of frequencies and higlier accelerating gradints.

Two basio of considurations in scaling a collider lima with frepluency anw

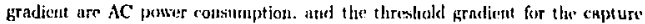

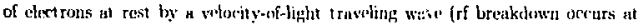
grodicents well above this threshold). At 2856 MHz the durk current ihreshold gradient is about $15 \mathrm{MV} / \mathrm{m}$. It is artainly gussible to uporate a lina komewhat 
in excess of this threshoid grudient, but it sould be dangerous to propose a design excerding the threshold by too large a factor. Withi frequency, the dark current caph ture thredold seales as $G_{t h} \sim \omega$ and the ncelerater length as $L \sim E / \omega$, where $E$ is the center-of-mnss collision energy. At constant repetition rate and ratio of $r f$ pulse length to structure filling time, the $A C$ power would hlso scale sts $P_{a c} \sim E / \omega$. In going to a higher muchine energy, it is therefore clearly desiruble to go to a ligher of frequenty: There are, loutever, mijor disadwantages that go along with a higher frequency: The dipole mode (deflecting) wake potential per unit length of st ructure incrastes roughly as $w^{3}$, and this in turn leads to tightor nlignment and thanufncturing lolerances.

At SLAC. a lineat collider design has been proposed (the NLC, or Next Linear Collider) at a frequency of $11.4 \mathrm{GHz}$. There is 10 strong theoretical reason for this exart choice of frequency. The original (rather weak) ctmsiderations behind this frepuency chotce for an NLC were first, to stuy within $1 \mathrm{l}_{\mathrm{u}} \mathrm{x}$-thand frequency range, whi sceond, to be an integral multiple of the SLC frequetscy of $2856 \mathrm{MHHz}$. X-band was taken as an upper frequency limit becamse the terbuology is still relatively "comfortable" at this frequency; that is, of compmusuts are reasomole in theis size, weight, tolerunces, price and avnilubility. Also, small industrinl accelcrators are routinely built at this freguency. It whis also felt that high power klystrons could be built at $11 \mathrm{GHz}$ witb a power oust put in the $50-100 \mathrm{MW}$ range. As it turned out, building a klystron with this output power and also high efficiency (> 50\%) was perhaps a grenter challenge thas had bern expected.

Table 1 shuss some basic ff-related parnmeters for several passible future linedar colliders. All entries tssume a repetition rate of $120 \mathrm{~Hz}$. The notive linas: jengtli incindes both $e^{+}$and e lithes, and nsiumes twis $10 \mathrm{GeV}$ injextors plus a $7 \%$ overhead for off-crest (BNS) operation and klytron fallure matugement. 
Table 1

Basic RF Parameters for Future Linear Colliders

\begin{tabular}{|c|c|c|c|c|c|c|c|c|}
\hline 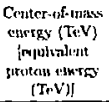 & $\begin{array}{c}\text { RF } \\
\text { Ineyluesicy } \\
\text { (Gtuly) }\end{array}$ & 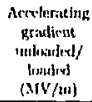 & 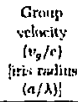 & 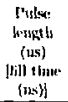 & 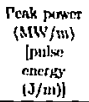 & $\begin{array}{l}\text { Aerr! } \\
\text { Ematox } \\
\text { slrurture } \\
\text { Iength } \\
\text { (In) }\end{array}$ & $\begin{array}{l}\text { Aetlise: } \\
\text { lisine } \\
\text { tengtlt } \\
\text { (kin) }\end{array}$ & 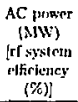 \\
\hline $\begin{array}{l}1.0 \\
\mid 10 !\end{array}$ & $\begin{array}{c}11.4 \\
4 \times S I C C\end{array}$ & $8: 5 / 03$ & $\begin{array}{l}.66 \\
{[.175]}\end{array}$ & $\begin{array}{l}220 \\
100 ;\end{array}$ & $\begin{array}{l}145 \\
{[32]}\end{array}$ & I.B & 17 & $\begin{array}{l}185 \\
{[34]}\end{array}$ \\
\hline $\begin{array}{c}1, \hat{f} \\
\mid \mathrm{LHC} \text {. }\end{array}$ & 11.4 & IKa/75 & " & " & 200 & $"$ & 21 & $\begin{array}{l}225 \\
\text { (G) }\end{array}$ \\
\hline $\begin{array}{c}5 \\
{[\mathrm{SSC}]}\end{array}$ & $\stackrel{34}{12 \times S L C}$ & $2(x) / 154$ & $\begin{array}{l}.20 \\
{[.215\}}\end{array}$ & (2A) & $\begin{array}{l}535 \\
\{2 i i\end{array}$ & 0.6 & 35 & $\begin{array}{l}225 \\
{[501]^{\prime}}\end{array}$ \\
\hline $\begin{array}{l}25 \\
{\left[25 \pi 11^{\circ}\right.}\end{array}$ & $\begin{array}{c}113 \\
36 \times S L C\end{array}$ & $4: 11 / 3 ; 31$ & $\begin{array}{l}.167 \\
! 265 !\end{array}$ & $\begin{array}{l}12 \\
|;|\} \mid\end{array}$ & $\begin{array}{l}1805 \\
(22)\end{array}$ & 0.25 & 811 & $\begin{array}{l}515 \\
{[5011]}\end{array}$ \\
\hline
\end{tabular}


The first antry shows the NLC parsmeter choices for a 1 TeV collider, with it loaded gradient that is just at the datk corrent capture threslould. The ri system compotutts (klystron. modulitor and of pulse compression system) are bikied on modest extrapolations of demonstrated technology, backed by simulations. The PPM-focusel klystras (one for esery iws accehrnting structums) bave an output power of $72 \mathrm{MWW}$. a palse length of $1.2 \mathrm{ks}, \mathrm{a}$ mirropervinuce of 0.75 and a simulaled efficiuncy of $03 \%$ (1) The modulator has an werall elliciency of $75 \%$. biked on a Blumlein-1ype putse forming network (PFN) and a pulse transformer with a turns ratio of 7:1. This low turns tatios allows a high efficiency for the transfer of energy stoted in the PFN through the pulse transformer to the fiat top portion of the ingh voltige pulse applied to the klystron cathode [sec (2) for a brief discassion of modulutor efticiencre. The of pulse comprexion system is a SLED-If type system (3) with a compression ratio of 5, a pouver gain of 3.6 and an overnll efliciency of $72 \%$, includieng $4.5 \%$ allonance for bosscs ift the compenents of tice pulse comprossion system, and a th Hlowance for lossts in the power transmission components from klystron to pulse compression system to accelersting structure. The overnli of system efficiency is then the product of the three subsystem officiencits (klystron. modulutur, rf pulse compression), or respextively $63 \% \times 75 \% \times 72 \%=31 \%$.

The next cutry in Tablu! I shows bisje paraneters for a 1.5 TeV $x$-lyand collider

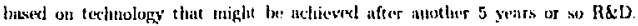
The klystron hiss a proks power ontput of $112 \mathrm{MW}$ it wh efticiency of $70 \%$. This output power and efficiency might be achicued by either a cluster klystron (4) or a steet bean klystron (5). It is assumes that the klystrun has a gridded gon to suritu the bean (elimionting the need for a modulator), and that this switching eun be ucromplished with an afficiney of $90 \%$. 'The pmbe compression system is 
assuned to be a thres stage binnty julse compressor ( $\mathrm{BPC}$ ), with an elficiency of $80 \%$ (including a $5 \%$ allowance for power transmission losses), and a power gain of $6.4(8 \times 0.80)$. The BPC system is based on the ust of lumped resonant elements, rather than snooth delay lines, thus rulucing the delay line lengeh per unit of delay by a factor of 50 or so. Details are given in a later section. The overad ff system efficiency is therefore $70 \% \times 90 \% \times 80 \%=50 \%$.

The $1.5 \mathrm{TeV}$ collider in Table $\mathrm{J}$ is probably elose to the energy limit that can be achiested with $\mathbf{x}$-lonnd technology. Still hipher entergitis will tequire still ligher rf frequencies. The mext nntry; $5 \mathrm{TeV}$ center-of-mass collider, hats an if froquency of $34 \mathrm{GHz}$ and a loulded gradient of 150 MIV/m (the durk cutrent capt ure arailient is about $185 \mathrm{MV} / \mathrm{m})$. An tf frequency on the order of $30 \mathrm{Gllz}$ is not unremsimnbly "exotic." Prototype acceleruting structures liave been built at this frequency, and it is indeed the frequency thesen for the CLIC linır collider proposed at CERN, Geneva, Switzedand. Extesisive RES hes buen carried out al $30 \mathrm{GHz}$ in support of the CLIC proposal [see, for example. Ref, (bi)). Specific beam parameters for a $5 \mathrm{TeV}$ collider with a luminosity of $2.5 \times 10^{3 \mathrm{w}} / \mathrm{cm}^{2} / \mathrm{sec}$ haw also been stergested (7). An rf systemn eflicienry of $50 \%$ is agin nsammed.

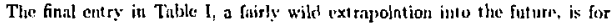
a $25 \mathrm{TaV}$ limear collider operating at an if freduency of $103 \mathrm{Gl}$. In itsulf, this bigh a frequ'ney is not of concen. Generating and transmitting tuegawatls of

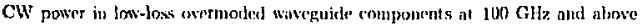

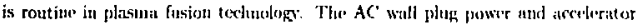

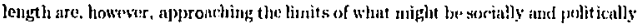

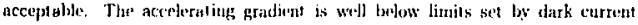

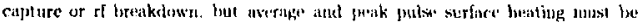
considered. The of energy per polse is uetually lose than that for the l tev 
$x$-band design, but the surfuce area per meter of length is down by a factor of nine. Thus the average power dissipntion per unit area of cylitudrical structure surface (proportional to $\omega U_{m}$, where $U_{m}$ is the energy per pulse per neter) is about six times that at $x$-band, or about $20 \mathrm{~W} / \mathrm{cm}^{2}$, Careful cooling channel desiph should be able to take care of this licnt load. The surface tenperature rise at the end of the pulse (proportionul to $C^{2} \omega^{1 / 2} \tau_{p}^{1 / 2}$ where $\tau_{p}$ is (lie pulse length) is up by a factur of about 20 over that at $x$-band, to about $200^{\circ} \mathrm{C}$. This is probably above the thrushold for surfuce degradiation one to the stresstes induced by lemperature cycling. Perhapss a surface treatment, or a new structure design, can be developed to aneliorate this effect.

The sealing with if freyuency and collider onersy implicit in Table $I$ is approxiunately

$$
\begin{aligned}
& \omega \sim E^{2 / 3} \\
& G \sim \omega^{3 / 1} \sim E^{1 / 2} \\
& I \sim E^{1 / 2} .
\end{aligned}
$$

where $C$ is the uccolerating gradient. As frecuuncy is incristed, the iris opening is increisnd $\left(0 / \lambda \sim \omega^{102}\right)$ to nincliorate waknfield effects aml to incrense the group velutily $\left(v_{g} \sim \omega^{1 / 2}\right)$, which in turu incresses the section length such that $L_{a} \sim \omega^{-1}$. However, a larger iris opening also retuces the notmulized ciastance approximately as $s_{n} \sim w^{-1 / 6}$. The penk of power per nncter and the energy per pulse per meter then scale approximatuly as

$$
\begin{aligned}
& \hat{P}_{m} \sim \frac{C^{2}}{s_{n} \nu^{2} \tau_{f}} \sim \omega^{j / i} \sim E^{0, *} \\
& U_{m} \sim \nu^{-1 / a} \sim E^{a 2 .}
\end{aligned}
$$

The totul AC power is then $P_{u r} \sim U_{m} L \sim E^{0.3}$. 


\section{COMMENTS ON RF SYSTEM EFFICIENCY}

Fullowing are somu general comments on the cficiencies of the thee major subsysterns which make up the rf byst mu for a klystron-driven linenr collider. At at constant beam voltage, the if output of a klystron (or other mitrok'ave if soufce)

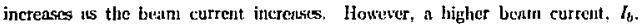
at $a$ given beam voltage, $V_{b}$ inevitubiy leads to a lower efficiency because of the detrimental effects of space charge forces. These forces iend to blow apart the shapply defined bunches necded fur ligh output efliciency. Th/ micropervance (defined as $K_{\mu}=J_{b} / V_{b}^{j / 2} \times 10^{j}$ ) is commonly takel as a measure of these spmes charge effects. Very roughly, the nuximum klystron efliciency [ser. for exanple. the plot in (4)! can be taken as

$$
T_{k \mathrm{ly}} \approx 0.80-0.15 K_{b}
$$

On an efficiency wrsus perveance glot, this line forms an uppre emelope for efficiency values obtwined from both measured performance aul fron simnlations. The intercept at zero perveance has some thenritical justification (8). Low frequency, long pulse or CW klystmons tem to fall closer to this perfornance limit than high frequency. high preak power tubes. The klystron output powar is then

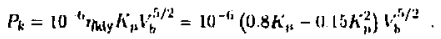

A mudalator providet the klystron bean soltage. usually by charging the

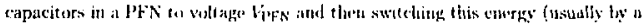

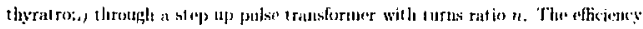

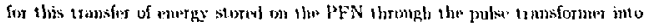


Ihe flat-top purtion of the output pulse is the energy transfer efficiency, t). This effieincy is less thun unity muinly becituse of onergy lost in the rise and fall times of thr output pulse. In turn, the rist: and fall timus are roughly proportional to the transforuce turus rntio, and to the square root of the pulse length. These relationshipiss can be summarized es:

$$
\begin{aligned}
V_{b} & =n N_{l} V_{\text {PFN }} \\
\eta_{E} & =\frac{A T_{k}}{T_{k}+B n T_{k}^{1 / 2}} \\
\eta_{\text {Houl }} & =\eta_{p s} \nu_{E} .
\end{aligned}
$$

Here $T_{k}$ is the flat-top portion of the morlulator output jonse; $N_{\ell}$ is the number of stages in the modulator PFN ( $N_{\ell}=2$ is a Blumlein volt nge doubling arrangentent, cte.); the ronstain A takes ncconn of transformer core losses, resistive loses in the transformur windings und leuds, and losses in the llyratron 0.97 unight be a reasonable vilue for $\mathrm{A}$ ); $\eta_{p,}$ is the efficiency for converting energy frum the $\mathrm{AC}$ line to energy storcd on the PFN, taking into nccount losses in the power supply and clarging circuit $190 \%$ is eusy, $95 \%$ is hard?

The if pulse compression system compresess the klystron output pulse by a ratio $R=T_{k} / T_{\text {fi }}$. where $T_{\mathrm{rl}}$ is the pulso length deliwed to the accelerating structures: "lye net pulse compresion efliciency in the product of an intrinsirefficiency. Mont, and a loss efficiency, nem. which is less than one due to copper lasses. บ1wunted reflections. nnd mode conversion in a systen using overnoded

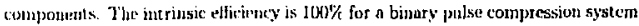
(9). or BPC: fur a SLED -Il system it is a decreasing function of compression ratio ( 1 int $=0.86$. 0.80. 0.75. and 0.64 [or $R=4,5,6$, and 8 respectively). The loss 
efficiency component also tends to decrease: with increasing $R$ for both types of compression systems. Summturizing:

$$
\begin{aligned}
& \eta_{\mathrm{rr}}=\eta_{\mathrm{uL}}(R) \eta_{h_{\mathrm{rav}}}(R) \\
& G_{y}=\eta_{j \times} R .
\end{aligned}
$$

where $G_{p}$ is the power gain.

The preceding equations show that the three systenu eficiencics cannot be optimizad scparately, without lexding to inconsistent results. The sume conelusion also apjylies to sysitem costs. For example, a gond klystron efliciency implits a low perveance and therefore 4 high baun volt nge for a fiven power output. From Eg. (2), a high bean voltage implies some combination of $n$ large transfonner turns ratio (result ing in low $\eta_{E}$ ), or a value of $N_{\ell}>1$ (more difficult technically and more

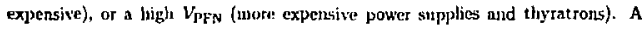
high pulse compresion efficiency implies low comprestion ratio, and thesefore mort klystron pouter al a shorter pulse length. If the pereance is incressed to obt tist the ligher power, klystron per[ormance suffers. If the benm voltuge is incrensed, eit her the modulater affiency must decrease, or the cost must incrense. In either case, the shorter klystron pulse length also tends to decrenue the modulator efficiciry. If the pulse comprosision system is eliminated ontirely, at in a two-beam accelerator, mere de pulse compression twust be carriod out in the induction linac nodules. The not if system afficiency tomb to be uhout the smane (on the order of $30-40 \%$ ).

\section{HIGH GAIN RY PULSE COMPRESSION SYSTEMS}

If an efficiency grater thu $70 \%$ is desirex. it is not possible to ust a stanturt SLED - 11 Iype puls: compresibion system with a compresion tatio grtater than six. 
The intriusic efficiency $(75 \%)$ at $\mathrm{H}=6$ limits the power gain to 4.5 . The effuct of copper losses in the delay lines and ot her woreguide components will furtier reduce the etliciency, resultimg in a net powar gain of perhaps 4.2. To achive high gain at high efficieny, rther methods of pulse compression must be considered. Some possibilitics which can deliver a flut ontput pulse with very high intrinsit: efficiency are: "chirping;" binury pulse compression, atul use of an setive swited to change the refiectim coeflicient of the iris in a SLED-II compression system. In the chirping scheine, the fretguency is modulated along the pulse such that the back of the pulso, travcling at a fister group velucity, catches up with the front of the gulse in a dispersive structure. It is used to produce very high gains in opticul conpression systems, but it is not inberently nuperior to the $\mathrm{BPC}$ melland in microwave systems using waveguide transmission components. Copper lossts limit any compression method to the same maximum energy storage time (and compression ratio for a given output pulse length), depending on achievable $Q$ 's for the delay components. An active switch (a laser-driven silion wafer), which could be applied to increase the efficicncy of a SLED-II system at lurge compression ratios, is currently being investignted at SLAC (10). This work. Lowever, is at a preliminary stuge, and in wly cose the switcl will impose some linit ation on poak prouer which is not yot well defined. Thereiore, we locus our attention on the possibility of achieving higher power grins using a $B P C$ systenu with a conpression rat io $R \geq 8$.

As mentioncd previously, the: $1.5 \mathrm{TeV}$ NIC design in Table I is basced on a threx-stage birmry pulse compresision syst'm with un elficiency of $84 \%$ (excluding pouer trausmission lossies). The design is bisted on using it relut ively snall number of overmoded. $T E_{m}$-mode cylindrical cavity resomitors. A cortain mumnt of ripple (a for percent) rau be tolerated an the output pulse of the BPC systern. Essentitily, pulse compression is achioved in such a BPC system by slicing the 
kiystron pulse into a number of tine bins equal to the compression ratio, and then stacking these bins to form the compressed output pulse. Amplitude ripple can therefore be compensated by phasis" modulating the individual time bins. half with a positive phase variktion and half witl an equal nogative phose voriation. This same scheme cin also compensute for the effects of modulator rijphle on the klyst rom output and more inportantly, to groduce an amplit ude ramp at the beginning of the If pulse which is needed to conpensate for boum louding (11). This ability to produce an arbitrary amplitude nodulation on the $\mathrm{rl}$ pulse is one of the strong points of if pulse conpresion. Of course, chergy is lost in the compensation process, so it is desireable: to keep the peak-to-peak ripple amplitude to the order of a few percent.

The $Q_{0}$ of a $T E_{01}-$ nunde cylindricit) copper resmator at $11.4 \mathrm{GHz}$ is [ignoring coupling holes).

$$
\begin{aligned}
Q & =\frac{2.58 \times 10^{4}}{y^{3}+(2.44 / n)\left(1-y^{2}\right)^{3 / 2}} \\
y & \equiv \lambda / \lambda_{r}=0.61(\lambda / a) \\
L_{F} & =n\left(\lambda_{y} / 2\right) \approx \mathrm{n}(\lambda / 2) .
\end{aligned}
$$

Here $L_{c}$ and a ure the length and radius of the cavity. flisimned to be $n$ half-wavelengthis long. The first term in the denominator represents tlu' los in

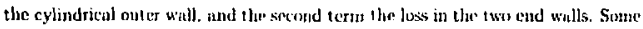

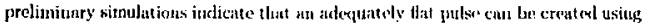
seven cavitics ger stage in a BI'C sygtem with dolay lines replaced by discrete cavitics. If the lenglh of radh covily is kepe to $1.5 \mathrm{~m}$. the delay circuit length for one stage ar compressign is liss than the b-11 s]ating betuesn comprosion 
syst mans (assuming four cavitits in one dirastion, a bend, and threc snvities in the nowerse direction). For this cavity leugth, $n \approx 110$. If we now cloose y so that the losi in the cylindrical outer wall is $10 \%$ of the loss in the end walls, we have an $a=12.5 \mathrm{~cm}$ and $Q=1.1 \times 10^{6}$. From $T_{0}=2 Q / \omega$, we have $T_{0} \approx 30 \mu \mathrm{s}$. Using $\eta$ (loss) $=\exp \left(-2 T_{D} / T_{0}\right)$ to calculute the loss per stage in a BPC system with delay tirnes of 220 ns, 440 ns, and 880 ns (for the $1.5 \mathrm{TcV}$ collider in Table I), wt: calculute $\eta(220 \mathrm{us})=0.985, \eta(440 \mathrm{~ns})=0.97$, and $\eta(880 \mathrm{~ns})=0.94$. The net loss efficiency is mow $=90 \%$. This lcaves an allowance or $2 \%$ per stage for other component losses in order to achiove an overull efficiency of $84 \%$.

\section{Table 2}

RF Source Requirements for Future Colliders Using Binary Pulse Compression

\begin{tabular}{|c|c|c|c|c|c|}
\hline $\begin{array}{c}\text { Energy } \\
\text { (TeV) } \\
\text { \{frcqususy } \\
\text { (GIlz) }\end{array}$ & $\begin{array}{l}\text { Station } \\
\text { length } \\
\text { (m) } \\
\text { [structures } \\
\text { /station] }\end{array}$ & $\begin{array}{l}\text { Conl- } \\
\text { pression } \\
\text { ratio } \\
\text { [pohticr } \\
\text { gain] }\end{array}$ & $\begin{array}{c}\widehat{P}_{\text {rf }} / \text { station } \\
\text { (MIV) } \\
\text { [pulse } \\
\text { enctgy/ } \\
\text { slution (.1)] }\end{array}$ & $\begin{array}{c}\text { Klystron } \\
\text { penk } \\
\text { power } \\
\text { (kiw) } \\
{\left[T_{k}(\mathrm{~ns})\right]}\end{array}$ & $\begin{array}{l}\text { Number } \\
\text { of } \\
\text { stations } \\
\text { [umulber of } \\
\text { klystrons] }\end{array}$ \\
\hline $\begin{array}{c}1.5 \\
{[11,4]}\end{array}$ & $\begin{array}{l}7.2 \\
{[4]}\end{array}$ & $\begin{array}{c}8 \\
{[0.4]}\end{array}$ & $\begin{array}{l}1440 \\
{[317]}\end{array}$ & $\begin{array}{c}112 \\
{[1760]}\end{array}$ & $\begin{array}{c}2960 \\
{[5920]}\end{array}$ \\
\hline $\begin{array}{r}5.0 \\
{[34 \mid}\end{array}$ & $\begin{array}{l}4.8 \\
{[8]}\end{array}$ & $\begin{array}{c}16 \\
{[12.8]}\end{array}$ & $\begin{array}{l}2570 \\
{[128]}\end{array}$ & $\begin{array}{c}100 \\
{[800]}\end{array}$ & $\begin{array}{c}7400 \\
\lfloor 14,800\}\end{array}$ \\
\hline $\begin{array}{c}25 \\
{[10 \mathrm{t} \mid}\end{array}$ & $\begin{array}{r}4.0 \\
{[10\}}\end{array}$ & $\begin{array}{c}32 \\
{[25]}\end{array}$ & $\begin{array}{l}7220 \\
{[87]}\end{array}$ & $\begin{array}{c}144 \\
{[385]}\end{array}$ & $\begin{array}{c}20,250 \\
|40,500|\end{array}$ \\
\hline
\end{tabular}

The: lirst entry in $\mathbf{i}$ nole 2 fhows the rf power source requirements for a $1.5 \mathrm{TeV}$ collider using the BPC system just describel. The second entry, based on a BPC system with a compression ratio of 16 , gives source requirement for the 5 TcV colliter in Table 1. A BPC with $\mathrm{R}=8$ at $34 \mathrm{GHz}$ could be scaled directly from the $11.4 \mathrm{GHz}$ dewi:n above, sime both the loss decrement time and the delny time 
scale as $\omega^{-3 / 2}$. To go to $\mathrm{R}=16$, the $Q$ and therefore the scaled cnvity length must be doubled. However, since the sumber of accelerating sirnetures por if station is also doubled, there is room to do this. The sane reasoning applies to the design of a BPC system for the $25 \mathrm{TeV}$ machine. However, as the cavity length is intreased relative to the wavelength, the cavity becomes more ovetmoded. The loaded $Q$ for a BPC cavity is $Q_{L} / Q_{0}=T_{k}\left(2 N T_{0}\right)$, where $N$ is the number of cavitics per stage. This ratio is $\approx 4 \times 10^{-3}$ for $N=7$ and a first stage tficiency of $04 \%$. Thus, unless care is taken, the bardwidth of the system could overlap a number of parasitic modes. These modes can be moved around in frequency to clear space for the desired mode by tailoring the radial profile of the eavity end disks, or longitudinal profile of the cylindrical outer surface. The use of an "open resonator" type of cevity (12) can also be considered.

\section{DISCLAIMER}

This report was prepared as an account of work sponsored by an agency of the United States Gowemment. Neither the United States Government nor any agency thereof, nor any of their employes, makes any warranty, express or implicd, or assumes any legal liability or responsibility for the accuracy, completeness, or usefulness of any information, apparatus, product, or procen disclowed, or represents that its use would not inftinge privately owned rights. Reference hercin to any specific commercial product, process. or servjec by trade name, trademerk. menciacturet, of otherwise does not necessarily constitule of imply its endorsement. 1 ecommendation, of favoring by the United Stetes Gavemment or any agency thereof. The views and opinions of euthors expressed herein do not necessarily state or refiect those of the United States Government or any agency thereof. 


\section{REFERENCES}

1. R. Phillips, private communicition

2. Wilson, P. B., "Application of Higli-Power Microwave Sources to ToV Linear Colliders," in Applications of High Power Aficrowaves, A. Gapouov-Grekhov and V. Grinatstein, eds., Boston: Artech House, 1904, cl. 7, pp. 287-290.

3. Refurence (2), pre. 293-297.

4. Pulmer, R. B., Herrmannsfeldt, W. B., and Eppley, K. R.. Particle Actel. 30, pp. 197-209. Also in SLAC-PUB-5026, SLAC, Stanlord, 1989.

5. Yu, D. U. L., Kim, J. S., and Wilson, P. B., "Design of a High-Power Sheet Bum Klystron," in AIP Conf. Pran. 279, New York: Am. Inst. Plyysics, 2993, תp. 85-102.

6. Wilson, L., "CLIC: The Design Scheme, Critical lsisues, and Stat us of That Facilities," CL1C Note 253, CERN, Geneva, Switzerland, 1994.

7. Irwitl, J., "A Bird's I. P. View of Linits of Comventional :te- Linear Callider Technology" presented at the 6th Workshop an Advanced Arcelcrutor Concepts, Lake Genevis, Wisconsin, June 12-18, 1991. Also in SLAC-PUB-6703, Sl,AC, Stanford, 1994.

8. Farkus, 7. D., and Wijsen, P. B., "Dynamics of un Electron in an RF Gap," SLAC-PUB-4898 Rev, SLAC, Stanford. 1989.

9. Farkus, Z. D., IEEE Trans. Mlisrowave Theory and Tecinjoues MTT-34, 1036-1013 (1986).

10. S. Tantawi, privati communicution.

11. Refurence (2). p. 251.

12. Balakin, V. E., and Syrncliev. J. V., "Stat us of VLEPP RF Powor Mlultiplier," in Proc. Inl Europtan Part. Acct. Com/. 1992, p. 1173. 